\title{
Role of SHG in Women Empowerment and Poverty Alleviation - A Case Study
}

\author{
K. P. Radhika*
}

Department of Commerce, PSG College of Technology, Coimbatore -641004, Tamil Nadu, India; kpradhika05@gmail.com

\begin{abstract}
The scheme of micro-financing through Self-Help Groups (SHGs) creates empowerment yielding situations for women to move from the state of marginalization to that of utmost importance for them in all the family and other social decisions. This study highlights the crucial role of SHGs in alleviating poverty among women in Karamadai block of Coimbatore district. The study revealed that the women members of SHGs have significantly gained psychologically, socially and economically that has led to their empowerment.
\end{abstract}

Keywords: Empowerment, Poverty, Sustainable Development, Upliftment of Women, SHGs

\section{Introduction}

Women's contribution in the development of both their family and the nation is highly incredible, as it mitigates gender disparity on the one hand and triggers an overall and sustainable growth in all spheres on the other hand ${ }^{1}$. According to UNIDO Report ${ }^{2}$ also endorses the same view by calling for organizing the potential skills of rural women to reap an economic growth that transforms people to live above the poverty line.

\section{Micro-Enterprises a Boon among the Women}

Micro enterprises aim at developing and utilizing the entrepreneurial talent and potential of rural and urban women below poverty line to meet their local needs. Ghosh ${ }^{3}$ asserts that the development of micro entrepreneurs among women are seen as appropriate way to assault poverty at the grass-root level by generating employment and income.

SHG, is a scheme launched by the NABARD allowing 10-20 women with common objectives to voluntarily involve in the productive activities assuring economic independence. The concept of SHG reiterates the principle of democracy "for the people, by the people and of the people".

\section{Review of Literature}

Thalavai Pillai and Nadarajan ${ }^{4}$ exposed that the SHGs have been a beneficial tool to aid the poor to satisfy their pressing needs through thrift. Rekha Goankar ${ }^{5}$ concluded that the SHG movement has brought in the mitigation of poverty and unemployment in the rural sector of the economy. Sahoo and Tripathy ${ }^{6}$ analyzed how SHGs brought about the micro credit intervention and in turn helped poverty alleviation. Vijayachandran Pillai and Hari $\mathrm{Kumar}^{7}$ in their study analyzed the role of SHGs among women of Kerala and found that these provide poor people to lead a self-reliant life. According to Ukanwa I., Xiong L. and Anderson $A^{8}$., for poor entrepreneurial women, microcredit was looked upon as debt with the probable risk of irreversible losses.

\section{Objectives}

- To study the socio-economic profile and performance of the women entrepreneurs in the SHGs.

- To study the impact of SHGs in the upliftment of the women and to reduce poverty.

\section{Methodology}

Primary data was used for extracting information from the members of the SHGs of Karamadai block with the help of a structured questionnaire. 100 respondents from 10 SHGS who were actively engaged in the block were approached and data 
regarding their demographic, socio-economic and factors influencing SHGs were collected by interview method. The data collection was executed and compiled during the period of November to December 2017.

The collected data were consolidated with the help of excel and the simple averages and composite weighted mean method was used to give a consolidated view of the changes in the profile of the respondents before and after joining the SHGs.

\section{Analysis and Interpretations}

\subsection{Socio-Economic Profile}

Socio-economic profile of the respondents has been probed to highlight the conditions of the respondents under study. In this context, the age, annual income and literacy status of the respondents have been focused as these are the key indicators of development of the citizens at the fundamental level. Table 1 gives the socio-economic profile of the SHG members under study based on the above mentioned three parameters. credit" followed by "for doing business" (27\%) and about $20 \%$ of the respondents joined for improving their saving habits.

Table 2. Rationale of joining SHG

\begin{tabular}{|c|l|c|}
\hline No. & \multicolumn{1}{|c|}{ Reasons } & No./ \% of respondents \\
\hline 1. & For getting loans and easy credit & 43 \\
\hline 2. & For promoting savings & 20 \\
\hline 3. & For doing business on small scale & 27 \\
\hline 4. & For other reasons & 10 \\
\hline \multicolumn{2}{|l}{ Total } & 100 \\
\hline \multicolumn{2}{|l}{} \\
\hline
\end{tabular}

\subsection{Income Level of the Members}

Income determines the standard of living of the people. As per Table 3, in the current study the members of the SHGs had a definite change in their income levels after joining the SHGs. There has been a predominant increase in the income levels, thus making the women members of the SHGs more independent to meet their personal expenditure and to contribute towards their household income. Many housewives (30\%) were not earning

Table 1. Socio-economic profile of respondents of SHGs

\begin{tabular}{|c|c|c|c|c|c|}
\hline Age Group & $\begin{array}{c}\text { No./ \% of } \\
\text { respondents }\end{array}$ & Education & $\begin{array}{c}\text { No./ \% of } \\
\text { respondents }\end{array}$ & $\begin{array}{c}\text { No./ \% of } \\
\text { respondents }\end{array}$ \\
\hline Less than 20 & 6 & Illiterate & 12 & Below 30000 & 21 \\
\hline $20-30$ & 25 & Primary & 34 & $30000-50000$ & 34 \\
\hline $30-40$ & 36 & Secondary & 26 & $50000-70000$ & 22 \\
\hline $40-50$ & 20 & Graduates & 18 & $70000-100000$ & 14 \\
\hline 50 and above & 13 & others & 10 & 100000 and above & Total \\
\hline Total & $\mathbf{1 0 0}$ & Total & $\mathbf{1 0 0}$ & $\mathbf{1 0 0}$ \\
\hline
\end{tabular}

Source: Surveyed data

The young and middle aged group people can more actively participate in the socio-economic activity and in the current study as per Table 1, the members of the SHGs in the age group of 30-40 was the highest (36\%). On the literacy front, most of the members had only primary schooling (34\%) and the illiterates were low (12\%) only. Annual income of the family gives a picture of the economic profile of the respondents. As per Table 1 in the current study most of the respondents (34\%) had an annual income in the range of Rs. 30000-50000 only.

\subsection{Rationale of Joining SHG}

SHGs aim to promote savings and facilitate the availability of credit for income generation activities among the members of the group. In the current study also many respondents have joined SHGs to promote their personal saving habits and to get credit in the form of short-term and medium-term loans for their productive activities. Table 2 gives the reasons stated by the respondents for joining SHGs and it is clear that most of the respondents (43\%) joined SHGs "for getting loans and easy anything before joining SHGs, but after their membership were earning satisfactorily.

Table 3. Monthly income and number of members before and after joining SHGs

\begin{tabular}{|l|l|c|c|}
\hline No. & Monthly Income (Rs.) & $\begin{array}{c}\text { Before Joining } \\
\text { SHG } \\
\text { (No./\%) }\end{array}$ & $\begin{array}{c}\text { After Joining } \\
\text { SHG } \\
(\text { No./\%) }\end{array}$ \\
\hline 1. & Less than 1000 & 8 & 3 \\
\hline 2. & $1000-2000$ & 12 & 10 \\
\hline 3. & $2000-3000$ & 33 & 40 \\
\hline 4. & $3000-4000$ & 4 & 10 \\
\hline 5. & $4000-5000$ & 6 & 30 \\
\hline 6. & $5000-6000$ & 5 & 3 \\
\hline 7. & Above 6000 & 2 & 2 \\
\hline 8. & Non-earning members & 30 & 2 \\
\hline & Total & 100 & 100 \\
\hline
\end{tabular}




\subsection{Family Monthly Expenditure of the SHG Members}

The expenditure of the families had also enhanced due to adequate increase in the SHG members' income. The relative income enhanced the expenditure pattern of the family boosting their savings after they joined the SHGs. Table 4 indicates the change in expenditure pattern among the SHG women before and after joining SHGs, which clearly shows a positive shift in the expenditure pattern among the families of the women SHG members in the select area.

Table 4. Monthly family expenditure of the members before and after joining SHGs

\begin{tabular}{|c|c|c|c|}
\hline No. & $\begin{array}{c}\text { Monthly expenditure } \\
\text { (Rs.) }\end{array}$ & $\begin{array}{c}\text { Before joining SHG } \\
\text { (No./\%) }\end{array}$ & $\begin{array}{c}\text { After joining } \\
\text { SHG } \\
\text { (No./\%) }\end{array}$ \\
\hline 1. & Less than 1000 & 25 & 10 \\
\hline 2. & $1000-2000$ & 45 & 25 \\
\hline 3. & $2000-3000$ & 15 & 40 \\
\hline 4. & $3000-4000$ & 10 & 10 \\
\hline 5. & Above 4000 & 5 & 15 \\
\hline & Total & $\mathbf{1 0 0}$ & $\mathbf{1 0 0}$ \\
\hline \multicolumn{2}{|c|}{ Source: Surveyed data }
\end{tabular}

\subsection{Credit and SHGs}

One of the major causes of joining SHGs is to obtain easy credit and debt facilities. The SHGs in the select area provide loans to their members for income generating activities as a group and debts to individuals for various purposes like business debts, marriage debts, repay the old debts, medical loan, house repairing loan, cattle loan etc. Based on the type of debt availed, the respondents were tabulated as given in Table 5 .

Table 5. Types of debts availed and number of respondents availing loan in the SHG

\begin{tabular}{|c|l|c|c|}
\hline No. & Types of debts availed & $\begin{array}{c}\text { Maximum amount } \\
\text { (Rs.) }\end{array}$ & $\begin{array}{c}\text { No. /\%of } \\
\text { respondents }\end{array}$ \\
\hline 1. & Business debts & 20,000 to 25,000 & 32 \\
\hline 2. & For marriage & Upto 20,000 & 12 \\
\hline 3. & To repay old debts & 10,000 to 15,000 & 14 \\
\hline 4. & For medical purposes & 10,000 to 15,000 & 18 \\
\hline 5. & For house repairing & Upto 5,000 & 11 \\
\hline 6. & As cattle loan & 5,000 to 7,500 & 13 \\
\hline & Total & & 100 \\
\hline
\end{tabular}

It can be inferred from Table 5 that a majority of the members of the SHGs in the study area had availed loans for income generating activities i.e., to start business which has fulfilled the motive of the SHG formation in the study area. Besides the 'business debts', among the individual loans availed by $32 \%$, the next higher number of respondents (18\%) had borrowed for 'medical purposes'.

\subsection{Impact of SHG on the Life of Women}

SHGs not only facilitated savings and credit opportunities to its members. It also brought about socio-economic empowerment of the women who joined the SHGs. They were empowered on the economic, individual and family grounds. The socio-economic impact of the SHGs on the women were assessed using factors such as self-confidence, awareness of social and economic aspects, changes in the education level, decision making, leadership qualities developed and degree of economic independence. Weighted average analysis was carried out employing five points rating scale and fixing score 1 for 'strongly disagree'; 2 for 'disagree'; 3 for 'neutral'; 4 for 'agree' and 5 for 'strongly agree' for these factors after joining the SHGs and the final results are given in Table 6.

Table 6. Indicators of empowerment after joining SHGs

\begin{tabular}{|l|c|}
\hline Indicators of empowerment & Weighted average \\
\hline Increase in Self-confidence & 4.6 \\
\hline Economic independence & 3.6 \\
\hline Change in education level & 2.4 \\
\hline Increase in social and economic Awareness & 3.9 \\
\hline Leadership qualities acquired & 3.7 \\
\hline Decision making & 4.2 \\
\hline Souce: Surveyd
\end{tabular}

Table 6 clearly indicates that the weighted average scores against the indicators of empowerment since joining SHGs range from 2.4 to 4.6. 'Increase in self-confidence' has the maximum weighted average and 'change in education level' shows the least weighted average. 'Decision making' and 'Increase in social awareness' were also found to be higher after joining the SHGs.

\section{Key Findings of the Study}

- The young and middle aged group people can more actively participate in the socio-economic activity and in the current study the members of the SHGs in the age group of 30-40 were the highest (36\%).

- A maximum of $34 \%$ of the members had only primary schooling.

- Most of the respondents (43\%) joined SHGs 'for getting loans and easy credit' followed by 'for doing business' (27\%) and about $20 \%$ of the respondents joined for improving their 'saving habits'.

- 'Business debts', among the individual loans availed stood the highest with $32 \%$ of the respondents, followed by $18 \%$ of them for 'medical purposes'. 
- 'Increase in self-confidence' had the maximum weighted average and 'change in education level' had the least weighted average. 'Decision making' and 'Increase in social awareness' were also found to be higher after joining the SHGs.

\section{Conclusion}

The present study has divulged that the majority of women sample respondents as members of SHGs have significantly gained psychologically, socially and economically. Hence, SHGs undeniably contribute to poverty alleviation and empowerment of poor, specifically the rural women.

\section{References}

1. Jha BK. Globalization and women empowerment: multidimensional approaches. Kumar B, editor. Deep and Deep Publications; 2009.
2. UNIDO Report; 2003. Available from https://unido.org

3. Ghosh. Women and entrepreneurship in India. Kanungo R, editor. Entrepreneurship and Innovation. New Delhi: Sage Publication; 1998.

4. Pillai NT, Nadarajan S. Impact of microfinance - An empirical study on the attitude of SHG leaders in Kanyakumari DistrictTamilnadu. International Journal of Enterprise and Innovation Management Studies (IJEIMS). 2010 Dec; 1(3).

5. Gaonkar RR. Working and impact of Self help groups in Goa. Indian Journal of Agricultural Economics. 2001; 56(3): 465.

6. Sahoo RK, Tripathy SN. Self help groups and women empowerment. Anmol Publications; 2006. p. 42-3.

7. Pillai V, Harikumar VB. Self- help groups in Kerala. Kurukshetra. 2006; 54(9): 30-3.

8. Ukanwa I, Xiong L, Anderson A. Experiencing microfinance: effects on poor women entrepreneurs' livelihood strategies. Journal of Small Business and Enterprise Development. 2018; 25(3):42846. Available from: https://doi.org/10.1108/JSBED-02-2017-0043. 